Extensions of their present fellowships have been granted to:

Norman R. Bennett (Boston): Completion of research on Islamic penetration of East and East Central Africa and writing of dissertation (England, Washington, D.C., Boston).

Victor D. Du Bois (Princeton): Completion of doctoral dissertation on the Guinean Independence Movement (Princeton).

William H. Friedland (Berkeley, California): Completion of research on trade unions and workers and of doctoral dissertation (W. Africa, Berkeley, California).

Willard R. Johnson (Johns Hopkins): Completion of program of African studies with emphasis on political science and economics (Johns Hopkins).

Herbert S. Lewis (Columbia): Completion of doctoral dissertation on the rise and development of the Galla kingdoms of Ethiopia (Columbia).

Marvin P. Miracle (Stanford, California): Completion of doctoral dissertation on maize in Tropical African agriculture and diets (Stanford, California).

Phyllis F. Neulist (Northwestern): Completion of doctoral dissertation on culture patterns among the Wagenia of the Belgian Congo (Northwestern).

John E. Peterson (Northwestern): Completion of research on an historical study of Freetown, Sierra Leone and of doctoral dissertation (England, Northwestern).

William A. Shack (London School of Economics): Completion of research and doctoral dissertation on the development of Gurage social structure in Ethiopia (London School of Economics).

Aristide R. Zolberg (Chicago): Completion of doctoral dissertation on the development of institutions of self-government in the Ivory Coast (Chicago).

The following have been awarded fellowships for African studies at American universities :

Ralph A. Austen: Program of African studies at Harvard and Boston Universities.

Thomas L. Blair: Program of African studies at Boston University.

Michael F. Lofchie: Program of African studies, with emphasis on political science, at the University of California, Berkeley.

Gerard Lucas: Program of African studies at Stanford University and Hoover Institute.

John A. Rowe : Preparatory study of the historiography of East Africa, at the University of Wisconsin.

\title{
Oxford Library of African Literature
}

THE Clarendon Press will shortly begin the publication of a series of volumes of the indigenous poetry and prose of Africa under the General Editorship of Professor E. E. EvansPritchard, with Dr. W. H. Whiteley and Dr. Godfrey Lienhardt as Assistant Editors. Each volume will consist of an English translation of a text or texts of cultural value and interest, together with an introductory essay and notes by a scholar familiar with the language and life of the people represented. Where the number of speakers of an African language justifies it, the whole of the vernacular text may be given with parallel translation. Otherwise, representative specimens of the original text will be included. The Oxford Library of African Literature is intended to place Africa among other continents of the world as a source for literary scholarship. The volumes will be chosen to cover as wide a range of African peoples as possible, and works already under consideration include texts from Ghana, Tanganyika, Northern Rhodesia, Bechuanaland, and the Sudan. It is hoped also that this series will 
encourage the further collection and full interpretation of works now committed to memory which may otherwise be lost to future students of African history and culture.

\section{The Papers of Sir Joseph Banks}

THE Library of the Royal Geographical Society has recently acquired xerographic prints of two sets of papers which are of considerable importance for the history of African exploration. This has come about as the result of a search for papers bearing on the history of the 'Association for the Discovery of the Interior Parts of Africa', which, founded in 1788 , was amalgamated with the Royal Geographical Society in 1830 . On that occasion, the R.G.S. apparently received none of the Association's documents. It seemed probable that a likely resting-place for them would be with the papers of Sir Joseph Banks, a founder of the Association and later President of the Royal Society from 1778 to 1820 . His papers are now distributed among numerous libraries throughout the world. On the suggestion of Miss Mander Jones, formerly Librarian of the Mitchell Library, Sydney, an approach was made to Mr. Richard H. Dillon, Libratian of the Sutro Library, California State Library, San Francisco. Mr. Dillon very kindly allowed the section of Banks's papers in his Library dealing with African affairs to be microfilmed, and from these films enlarged prints have been made by the Rank-xerox process. These prints amount to approximately 900 sheets, including a few printed pamphlets, and include letters to and from Sir Joseph Banks on actual or potential African travellers from 1788 to I 820 , documents concerning the organization, meetings, and finances of the Association, papers on the trading ventures of the African Company and the Sierra Leone Company, and memoranda and notes on a variety of subjects, such as the introduction of plants into Sierra Leone, possibilities of establishing communications and trade with the interior, and the appointment of consuls. It is hoped that these papers will shortly be thoroughly calendared.

A further line of inquiry led to the location of the three manuscript minute books of the Association in the University Library, Cambridge. These had formed part of the collection bequeathed to the Museum of Classical Atchaeology by Colonel William Martin Leake, the last Honorary Secretary of the African Association. Through the good offices of Mr. H. R. Cheswick, University Librarian, the Library Syndics generously presented to the Royal Geographical Society a microfilm of these three folio volumes, which cover the complete lifetime of the African Association, and constitute the primary source for any assessment of its role in the history of the modern exploration of Africa. They are also of special interest to the Royal Geographical Society, since it was the latter which took over and widened, during the nineteenth century, the work of African exploration inaugurated by the Association in the closing decades of the eighteenth century. But for the outbreak of the Napoleonic wars, it is not going too far to suggest, the foundation of the R.G.S. might have been antedated by twenty years. The Society therefore plans to publish an annotated edition of these minute-books as a first step towards the inauguration of its own record series.

[Communicated by Mr. G. R. Crone]

\section{The Journal of African History}

The Journal of African History, the first number of which has recently appeared, is edited by R. A. Oliver and J. D. Fage, with an advisory editorial board composed of representatives from African, Belgian, British, French, and United States universities. The first issue of the Journal contains ten articles and a large number of book reviews.

Contributions may be in English or French and should be addressed to: The Editors, Journal of African History, School of Oriental and African Studies, University of London, 